\title{
ORGANIZING AND SUSTAINING INCLUSIVE LEARNING ENVIRONMENT: INTERNATIONAL PRACTICES
}

\author{
SERGIY SYDORIV
}

\begin{abstract}
Teacher training in different countries has its peculiarities. Principles of inclusive education are universal, yet existing societal beliefs and values, policy and hidden curriculum in schools and preschool, parental support and advocacy demand taking them into account. In order to adhere to the principles and ideas of inclusive education teachers should be able to organize and sustain inclusive learning environment in their classrooms and outside. It is researched that many countries have long history of including students with special educational needs and disabilities and their experience may be viable for teachers' trainers, administrators and educators in those countries who has just started inclusion on a national level. Sharing the best practices and strategies and adapting them to the local peculiarities is the key to successful inclusion students with disabilities. The article gives various examples of how scholars define inclusive learning environment, what its characteristics and components are. International legislation, which proclaims the right of a person to education and regulates inclusion is the model for national laws as well it is developed and influenced by them. The study identifies legislative models for implementing Article 24 of the CRPD consistent with its principles and obligations and suggests the priorities to be incorporated into domestic legislations. It is highlighted that every country has stories of success, best practices, which may prove highly effective, applied to educational systems of other countries. Therefore, as proved it is important to exchange these practices, conduct research and gather evidence to create effective inclusive learning environment and train preservice and in-service teachers to organize and sustain it.
\end{abstract}

Keywords: inclusive learning environment, response to intervention, multi-tiered systems of intervention and support, inclusive service learning, teachers training, inclusive education, international practices.

\section{INTRODUCTION}

Pre- and in-service teachers trained in Ukraine has recently seen the appearance and growing increase in introducing of inclusive education component. This is happening due to the new national law on education (2017) and subsequent documents that provide for the right of students and their parents to receive schooling in the community. Here Ukraine adheres to international legislation and practices at the same time taking into account national, mental, institutional peculiarities, finding its unique path. It is worth underlining that inclusive education is about celebrating diversity or teaching to diversity that provides for persons with and without disabilities, who still may have special educational needs. Teachers, students, parents, NGOs and governments should unite their efforts, 
share resources and effective practices in order to remove barriers for ALL students to be able to attend kindergartens, schools, colleges and universities creating inclusive learning environment. It is important to cooperate internationally, exchange strategies and practices, design curriculum and hold education events to share experience. Ukraine as the country with relatively short history of including students with special educational needs and disabilities (SEND) faces the problem of insufficient number of specially trained teachers able to organize inclusive settings from the scratch. That prevents persons with disabilities to realize their constitutional right to education. Thus, arises the problem of training qualified professionals ready to work in an inclusive educational and developing environment, especially in higher education. Training aims at: forming in students an integral view of the nature and main objectives of inclusive education; developing skills to implement individual approach in training and education of children with special needs; supplying future teachers with methods of interpersonal interaction with parents of children with special needs, generating skills of differentiated teaching and evaluation in conditions of inclusive education [4, p. 104]. The project "Without borders: Sustaining and Supporting Inclusive Education Learning Community" aims at developing mutual cooperation in this field.

\section{RESULTS AND DisCUSSION}

\subsection{RESEARCH METHODS}

The comparative method has made it possible to study international experience of implementing inclusive education. The application of this method allows to systematize research data on social and educational strategies of inclusion, as well as make certain forward-looking conclusions about theoretical and practical aspects of development of inclusive education in the context of reforming the system of national education taking into account international standards.

Content analysis has been used to analyze and generalize scientific, pedagogical, psychological and educational literature on inclusion of students with disabilities, published during the last decade in the socio-pedagogical context.

Hermeneutic analysis has enabled to highlight socio-pedagogical foundations of the development of inclusive education in the framework of mutual understanding and establishing a constructive pedagogical cooperation among all stakeholders of the educational process.

\subsection{WHAT IS INCLUSIVE LEARNING ENVIRONMENT?}

UN defines inclusive education as recognition of the need to work towards 'schools for all' institutions, which include everybody, celebrate differences, support learning, and respond to individual needs. It is important to stress out that inclusion is about changing old and creating new system of education values and principles rather than adapting a child to the system. Here inclusion differs from the 'integration' or 'mainstreaming' model of education, when students are supposed to change or become 'ready for' or deserve accommodation by the mainstream. By contrast, inclusion is about the child's right to participate and the school's duty to make the suitable learning environment for him/her. We must accept and value an individual student with his/her abilities, needs, values, aspirations, plans, we should support, assist and motivate for setting goals and achieving them. Here inclusive learning environment is a prerequisite.

There are various definitions of inclusive learning environment. We shall start with the primary resource that regulates national education. According to Ukraine's Law on Education (2017) translated for European Commission for Democracy Through Law (Venice commission), inclusive educational environment is a totality of conditions, ways and means of their realization for co-education, upbringing and development of education seekers based on their needs and capabilities [9].

The term inclusive educational environment is abundant in publications by Slavic scholars, whose English is not their first language (N. Kalinina, E. Zvoleyko, A. Smantser, E. Ignatovitch, S. Kalashnikova, I. Klimenko, A. Oschepkov, V. Salahova, M. Simanovskaja). International scholars 
tend to use the term inclusive learning environment. Though Julie Jones in her dissertation articulates "the term inclusive educational environment will refer to students with academic learning disabilities who receive academic benefit from the educational model $[5,19]$. It is worth stating that education standards need to consider the needs, values, plans and aspirations of all students in order to organize a beneficial learning environment. In our paper we consider both terms "inclusive educational environment" and "inclusive learning environment" without discriminating between them.

It is important to create such educational inclusive environment at school that will stimulate students for constructive, collaborative and contextual learning and development, taking into account individual differences, abilities and disabilities. Each child is unique in his/her development and perception of the world, so two children with the same disability may react differently to the same situation and have different cognitive needs [8]. In order to organize and maintain inclusive learning environment educators should take a system approach toward certain components:

socio-psychological (taking into account individual psychological development and behavior specific to a person in a process of social interaction, promoting ethical and moral standards in socialization and communication, adequate attitude to positive or negative traits in the behavior of others, pedagogical aiming at correcting deviations, forming habits of tolerant interaction between a child with special needs and classmates);

informational (availability of up-to-date regulatory and educational support of the inclusive process);

cultural and educational (pedagogical competence of participants of the educational process in inclusive schools that encompasses content, forms, methods, tools, innovative technologies);

logistical (availability of modern multimedia, audio and video facilities, adaptation of school's physical environment, taking into account elements of aesthetics in the interior of school) [1, p. 73-74; 4, p. 103].

Analyzing available resources, we can add the following advices for the teacher:

- Address barriers to participation, learning and resources to support all students within schools;

- Use ICT and other tools to support all learners in inclusive settings;

- Collaborate within school communities (teachers, teaching assistants, students, parents/carers) in order to establish a systematic framework of inclusive values and practices (e.g. UDL or co-teaching involving a general education and a special education teacher).

In the twentieth century there was the beginning of the recognition the right of education for all. Children's right to inclusive education is stated in international human rights law. All relevant international human rights instruments recognize the right to education without discrimination on any grounds, including gender, disability, ethnic background, and other aspects of identity. The inclusive education environment is the requirement for schools to be inclusive.

\subsection{LEGISLATION}

International law plays as a facilitator for the realization of the right to education of people with disabilities throughout the world. As the most recent, integral and legally binding international instrument to protect the rights of persons with disabilities, the Convention on the Rights of Persons with Disabilities (CRPD) put steps forwards for the protection of their right to education [2, p. 79-80]. The key international conventions are UNESCO Convention against Discrimination in Education (1960), International Convention on the Elimination of All Forms of Racial Discrimination (1965), International Covenant on Economic, Social and Cultural Rights (1966), UN Convention on the Elimination of All Forms of Discrimination against Women (1979), UN Convention on the Rights of the Child (1989), International Convention on the Protection of the Rights of All Migrant Workers and Members of Their Families (1990), UN Standard Rules on the Equalisation of Opportunities for Persons with Disabilities (1993), UNESCO Salamanca Statement and Framework for Action (1994), UN Convention on the Rights of Persons with Disabilities (2006). In the General Comments of the Committee on the Rights of Persons with Disabilities it is stated "a "whole educational environment": the committed leadership of educational institutions is essential for introducing and embedding the 
culture, policies and practices needed to achieve inclusive education at all levels and in all areas, including in classroom teaching and relationships, board meetings, teacher supervision, counselling services and medical care, school trips, budgetary allocations, any interaction with the parents of learners with and without disabilities and, when applicable, the local community or wider public" [3, p. 4].

The official modern international history of inclusion started in 1994 when representatives of 92 governments and 25 international organizations formed the World Conference on Special Needs Education, held in Salamanca, Spain. The dynamic new Statement on the education of all children with disabilities was agreed, which called for inclusion to be the norm. In addition, the Conference adopted a new Framework for Action, the guiding principle of which is that ordinary schools should accommodate all children, regardless of their physical, intellectual, social, emotional, linguistic or other conditions. All educational policies should stipulate that children with disabilities attend the neighborhood school that would be attended if the child did not have a disability. The Statement contains a commitment to Education for All, recognizing the necessity and urgency of providing education for all children, young people and adults within the regular education system. The international legislation can influence national legislation as well as be impacted by it.

Let us look at the law on inclusive education in various countries.

\subsection{INTERNATIONAL PRACTICES}

In the USA the Rehabilitation Act of 1973 (Pub. L. No. 93-112), the Education for All Handicapped Children Act (now referred to as the Individuals with Disabilities Education Act-IDEA) (first passed by the U.S. Congress in 1975) and the Americans with Disabilities Act (ADA; Pub. L. No. 101-336) of 1990 were passed to protect and promote the rights of people with disabilities in the U.S. Guided by similar principles, the UN adopted the Convention on Rights of Persons with Disabilities (CRPD) in 2006. The U.S. signed the CRPD in 2009, but to date has not ratified it. Although the principles behind the CRPD are inspired by and resemble those stated in the ADA and the Rehabilitation Act, some scholars posit that the CRPD goes further because it specifies the steps to take to ensure the rights of people with disabilities worldwide [11].

Being in effect for over 30 years the ADA regulates all spheres of public life, including education that should be accessible by all students. In order to create inclusive learning environment many strategies and methodologies have been researched and practiced which may be implemented internationally to create instructionally, physically, socially, and psychologically inclusive environments. They should work as a system in order to be effective.

Instructional inclusion is important factor in an effective inclusive education implementation framework. The following techniques are proved to be effective: UDL, multi-tier system of supports, direction instruction, differentiated instruction, guided reading, incremental rehearsal, peer assisted learning strategies, co-teaching, integrated learning. For instance, Response to Intervention (RTI) has the potential to serve as a preventative framework for students who show signs of falling behind academically due to a variety of language-based, socio-economic, or disability-related reasons. Moreover, this approach is an important tool for facilitating enhanced collaboration between general and special educators as well as specialists.

The goal of social inclusion is to promote ongoing, positive and social interactions between students with special educational needs and their peers. In order to sustain an effective inclusive learning environment, the following are recommended to use: cooperative learning, civic engagement and responsibility, inclusive service learning. The latter provides a necessary connection between academic content taught in the classroom and real life in the community that results in teaching and learning that is both more explicit and applied, thus making it more understandable, meaningful and relevant to students who are unlikely to benefit from abstract instruction. When service learning is undertaken in an inclusive manner, it demonstrated positive effects on typically developing peers, changes their attitudes towards people with disabilities highlighting the fact that although students with disabilities may require some additional resources they can be conceptualized as a resource themselves. By 
working together to address common problems, students with and without SEND learn about each other, discovering the gifts, capacities, and talents each one possesses as well as their commonalities. Discovering that we are a lot more alike than different places social relationships between members of the two groups within a decidedly different context and has the potential to lead to greater mutual understanding and support

Psychological inclusion refers to a person feeling valued and accepted as a member of the group at school and in the community. It includes circles of friends, inclusive service learning, and social networking programs both in and outside of classroom. Positive behavior intervention and support (PBIS) framework proved to be highly effective.

In many cases, implementation of these strategies is accompanied by the use of formative assessment that enables educators to monitor regularly student progress and change instructional and other approaches when current methods are not demonstrating effectiveness. Teachers need to have opportunities to learn about how to use the principles of universal design for learning, differentiated instruction, and cross-disciplinary collaboration to adapt teaching strategies to meet the needs of differently-abled students. They need to acquire data literacy skills so that the progress of students with SENs can be monitored and the success of their educational approaches evaluated [10].

In Sweden recently the National Agency for Special Needs Education and Schools has presented a working model for schools to explore to what extent all students have access to the education providing the most recent concept accessible education. Schools can explore to what extent they provide a social, pedagogical and physical environment that is accessible for all their pupils. In 2010, the Swedish government passed a new Education Act, which came into effect as of 2011. The Education Act - For knowledge, choice and security entails major reforms encompassing all levels from preschool to adult education, reflecting the current division of responsibilities between central and local. The legislation has undergone a comprehensive review aimed at drawing up a new and modern law that reflects the conditions in the school sector as well as the management by objectives approach in school governance. The Education Act (SFS 2010:800) states that access to equivalent education for all is the basic principle guiding Swedish education from childcare to young adulthood. Therefore, pupils in need of special support are not to be treated in a differential manner. A student at risk of not achieving the minimum proficiency requirements or experiencing other difficulties in their school situation, may, however, be in need of special support. The underlying premise is that students in need of special support should get the support they need in the regular class setting. Special education support is, therefore, to be integrated as much as possible into the framework of regular education [7, p. 345].

\section{CONCLUSIONS}

In view of the above-mentioned, we can draw the following conclusions:

- The inclusive educational environment as well as inclusive learning environment is relatively new notions in Ukraine that is why while training teachers, universities should devote a particular attention to introducing a special course with a large practice constituent.

- International experience and best practices should be shared among inclusive education community so that the countries with long history of inclusion can be models how to implement the practices avoiding mistakes they had already corrected.

- As the study proves inclusive education is a global and logical trend of societal development and it is important to conduct research and gather evidence to make effective inclusive learning environment. 


\section{REFERENCES}

[1] Budnyk O. Inclusive education. Publisher G. Kushnir, Ivano-Frankivsk, 2015. (in Ukrainian)

[2] Cera R. National Legislations on Inclusive Education and Special Educational Needs of People with Autism in the Perspective of Article 24 of the CRPD. In: Della Fina V., Cera R. (eds) Protecting the Rights of People with Autism in the Fields of Education and Employment. Springer, Cham, 2015. doi: 10.1007/978-3319-13791-9_4

[3] UN Committee on the Rights of Persons with Disabilities (CRPD). General comment No. 4 (2016), Article 24: Right to inclusive education, 2 September 2016, CRPD/C/GC/4. Available at: https://www.refworld.org/docid/57c977e34.html

[4] Dubkovetska I., Budnyk O., Sydoriv S. Implementing Inclusive Education in Ukraine: Problems and Perspectives. Journal of Vasyl Stefanyk Precarpathian National University, 3 (2-3) (2016), 99-105. doi:10.15330/jpnu.3.2-3.99-105

[5] Jones J Preservice teacher attitudes and intentions toward an inclusive educational environment: An application of the theory of planned behavior. All Dissertations. 461, (2009). Available at: https://tigerprints.clemson.edu/all_dissertations/461

[6] Kalinina N.V., Kalinin I.V., Oschepkov A.A., Salahova V.B., Simanovskaja M.A. The Use of Social Resources of Inclusive Educational Environment to Cope Difficult Situations by Adolescents. International Electronic Journal of Mathematics Education, 11 (7) (2016), 2527-2536.

[7] Öhman M. Swedish School Development and Inclusive Learning Environments: A Single Case Study. Pedagogická orientace, 27 (2), (2017), 344-360. doi: 10.5817/PedOr2017-2-344

[8] Tassoni P. Supporting children with special needs: A Penny Tassoni handbook. Hodder Education, London, 2015.

[9] The law on education. Adopted by the Verkhovna Rada on 5 September 2017. European Commission for Democracy Through Law (Venice commission), 2017.

[10] Tichá R., Abery B., Kincade L. Educational practices and strategies that promote inclusion: Examples from the U.S. Sociální pedagogika/Social Education, 6 (2) (2018), 43-62. doi: 10.7441/soced.2018.06.02.03

[11] Tichá R., Qian X., Stancliffe R., Larson Sh., Bonardi A. Alignment between the Convention on the Rights of Persons with Disabilities and the National Core Indicators Adult Consumer Survey. Journal of Policy and Practice in Intellectual Disabilities, 15 (3) (2018), 247-255. doi: 10.1111/jppi.12260

Address: Sergiy Sydoriv, Vasyl Stefanyk Precarpathian National University, 57, Shevchenko Str., IvanoFrankivsk, 76018, Ukraine.

E-mail: sydoris@yahoo.com

Received: 03.01.2020; revised: 14.02.2020.

Сидорів Сергій. Організація та підтримка інклюзивного освітнього середовища в навчанні: міжнародний досвід. Журнал Прикарпатського університету імені Василя Стефаника, 7 (1) (2020), $122-128$.

У статті висвітлено особливості організації інклюзивного освітнього середовища у різних країнах, в т.ч. локальні особливості підготовки вчителів до роботи 3 дітьми 3 обмеженими мождивостями здоров'я. Обгрунтовано, що принципи інклюзивної освіти є універсальними, однак наявні в суспільстві переконання та цінності, організація освітнього процесу та прихований навчальний план у закладах дошкільної та загальної середньої освіти, підтримка та адвокація зі сторони батьків часто вимагають делікатності та особливої уваги у їх впровадженні. Автором визначено, що для реалізації ідей і принципів інклюзивної освіти, педагоги повинні вміти й мати 
змогу організовувати та підтримувати інклюзивне освітнє середовище на заняттях та в позашкільній діяльності. Досліджено, що багато країн володіють значним тривалим досвідом включення дітей 3 особливими освітніми потребами та інвалідністю, який може бути надзвичайно корисним і важливим для підготовки педагогів у країнах, які лише нещодавно почали інкдюзію на державному рівні. 3'ясовано, що обмін дієвими практиками та стратегіями і адаптація їх до локальних особливостей - ключ до успішного включення дітей 3 особливими освітніми потребами та інвалідностями. У статті подано приклади визначення інкдюзивного освітнього середовища дослідниками, вказуються його характеристики та компоненти. Міжнародне законодавство, яке регулюе питання дотримання права на освіту, зокрема інклюзивну, слугуе базою для національних законодавств, а вони своєю чергою стимулюють появу нових інтернаціональних документів. У дослідженні визначено законодавчі, регудятивні та прикладні моделі для імплементації статті 24 Міжнародної Конвенції про права осіб з інвалідністю та надаються пріоритети для вкдючення в національні законодавства. Підкреслено, що кожна країна має свої історії успіху та найкращі практики, які мають потенціал бути високоефективними при впровадженні інклюзивної освіти в інших країнах. Доведено важдивість обміну стратегіями і практиками, проведення досліджень та збору доказової бази для творення дієвого інклюзивного освітнього середовища, підготовки й перекваліфікації педагогів, здатних його організовувати та підтримувати.

Ключові слова: інкдюзивне освітнє середовище, відповіді на втручання, багатоярусні системи втручання і підтримки, інкдюзивне навчання в служінні громаді, підготовка педагогів, інкдюзивна освіта, міжнародний досвід. 